\title{
Characterization and Application of an Alginate Lyase, Aly1281 from Marine Bacterium Pseudoalteromonas carrageenovora ASY5
}

\author{
Yong-Hui Zhang ${ }^{1,2,3,+}$, Yuan Shao ${ }^{1,2,3,+}$, Chao Jiao ${ }^{1,2,3}$, Qiu-Ming Yang ${ }^{1,2,3}$, Hui-Fen Weng ${ }^{1,2,3}$ \\ and An-Feng Xiao 1,2,3, \\ 1 College of Food and Biological Engineering, Jimei University, Xiamen 361021, China; \\ yhz@jmu.edu.cn (Y.-H.Z.); 201711710036@jmu.edu.cn (Y.S.); 201711710029@jmu.edu.cn (C.J.); \\ yangqm@jmu.edu.cn (Q.-M.Y.); wwhhffen2020@163.com (H.-F.W.) \\ 2 Fujian Provincial Engineering Technology Research Center of Marine Functional Food, Xiamen 361021, China \\ 3 Xiamen Key Laboratory of Marine Functional Food, Xiamen 361021, China \\ * Correspondence: xxaaffeng@jmu.edu.cn; Tel.: +86-592-6180075 \\ + These authors contributed equally to this paper.
}

Received: 6 January 2020; Accepted: 30 January 2020; Published: 31 January 2020

\begin{abstract}
Alginate extracted from widely cultured brown seaweed can be hydrolyzed by alginate lyase to produce alginate oligosaccharides (AOS) with intriguing biological activities. Herein, a novel alginate lyase Aly1281 was cloned from marine bacterium Pseudoalteromonas carrageenovora ASY5 isolated from mangrove soil and found to belong to polysaccharide lyase family 7. Aly1281 exhibited maximum activity at $\mathrm{pH} 8.0$ and $50{ }^{\circ} \mathrm{C}$ and have broad substrate specificity for polyguluronate and polymannuronate. Compared with other alginate lyases, Aly1281 exhibited high degradation specificity and mainly produced di-alginate oligosaccharides which displayed good antioxidant function to reduce ferric and scavenge radicals such as hydroxyl, $\mathrm{ABTS}^{+}$and DPPH. Moreover, the catalytic activity and kinetic performance of Aly1281 were highly improved with the addition of salt, demonstrating a salt-activation property. A putative conformational structural feature of Aly1281 was found by MD simulation analysis for understanding the salt-activation effect.
\end{abstract}

Keywords: alginate lyase; brown seaweed; antioxidant; salt activation; molecular dynamics

\section{Introduction}

Alginate is a linear water-soluble polysaccharide that accounts for up to $40 \%$ of the dry weight of brown seaweed [1]. Alginate polysaccharide is composed of (1,4)-linked-D-mannuronic acid (M) and $R$-L-guluronic acid (G) with different structural arrangements (e.g., homopolymeric, MM-, GG-, or heteropolymeric, MG-, GM-). Due to the widespread cultivation of brown seaweed in Asia, alginate has been extensively studied for its extraction ability and is widely used as a viscosifier, stabilizer, and gelling agent in the food [2], chemical [3] and biomaterials [4] industries. Many recent studies have demonstrated that alginate oligosaccharides (AOS), which exhibit outstanding biological properties that differ from those of alginate polysaccharides, can be produced by further hydrolysis of alginate; in particular, AOS presents anti-antioxidant [5], anticoagulant [6] and antineoplastic [7] properties. Some studies have shown that AOS can lower blood sugar and blood lipid levels [8] and display anti-tumor [9] and anti-viral [10] abilities. Moreover, they can be used as prebiotic to promote the growth of probiotics, such as Bifidobacterium bifidum, Bifidobacterium longum [11], and Lactobacilli [12].

Alginate lyase can catalyze the degradation of alginate polysaccharides through a $\beta$-elimination reaction to cleave glycosidic bonds and produce AOS [13]. Thus, the development for alginate lyase is crucial to efficiently generate AOS. For example, AOS prepared by the lyase of Streptomyces sp. strain 
A5 shows growth-promoting activity in the roots of banana plantlets [14]. Zhu et al. [15] effectively produced oligosaccharides with 2-5 degrees of polymerization (DP) using a new endo-type alginate lyase from Vibrio sp. W13. Alginate lyases are mainly isolated from marine-derived organisms, including animals, bacteria, algae, fungi, and viruses [16,17]. Marine-derived alginate lyases often exhibit considerable salt-tolerance ability or salt-activation effects $[3,9,15,18]$ due to the high-salt marine environment in which the source bacteria are reproduced and evolve. The alginate lyase derived from marine Vibrio Harveyi-28, for example, exhibits a 24-fold increase in activity in $1 \mathrm{M} \mathrm{NaCl} \mathrm{[19].} \mathrm{Despite}$ the extensive development of alginate lyases and their widely observed salt-regulated properties, investigations into the salt-activation mechanism of alginate lyase are scarce.

In the present work, the novel alginate lyase Aly1281 was cloned from Pseudoalteromonas carrageenovora ASY5 and expressed in Escherichia coli. Its enzymatic properties were then characterized. Aly1281 can be used to hydrolyze sodium alginate, producing mainly di-alginate oligosaccharides, and exhibits high degradation specificity compared with other alginate lyases. In addition, the antioxidant capacity of the obtained AOS was investigated. A comparative molecular dynamics (MD) study was performed to study the salt-activation effect of Aly1281, as the lyase is significantly activated by addition of salt ions $\left(\mathrm{Na}^{+}, \mathrm{K}^{+}\right)$.

\section{Results and Discussion}

\subsection{Aly1281 Gene and Protein Sequence Information}

The alginate lyase gene was cloned, sequenced, and found to consist of $1089 \mathrm{bp}$. Its open reading frame (ORF) encoded 361 amino acids with a signal peptide of 26 amino acids predicted by using SignalP (http://www.cbs.dtu.dk/services/SignalP). The mature enzyme had a calculated molecular mass of $40.04 \mathrm{kDa}$ and a predicted $\mathrm{pI}$ value of 9.06. The sequence alignments of Aly1281 and the previous characterized alginate lyases of PL7 are shown in Figure 1A. The alignment indicated that Aly1281 was most closely related to alginate Lyase (PDB ID: 4BE3_A) from Zobellia galactanivorans with an amino acid sequence identity of $42.4 \%$. Aly1281 contained three highly conserved regions of PL family 7, namely, R(S/T)ELV(R/G), QIH, and YFK(A/L)GAYNQ, which played an important role in the substrate binding and catalytic activity of the enzymes $[15,17,20]$. Moreover, catalytic (Q173, H175, and Y315) and substrate binding (R104, E194, K197, E216, D228, and W327) sites were predicted in Aly1281 on the basis of previous research on alginate lyase (AlyA5) from Z. galactanivorans [21]. A phylogenetic tree was constructed (Figure $1 B$ ) according to the different families of alginate lyases, and the result showed that Aly1281 is located in the same clade with PL7 alginate lyases including BBH68061.1, AJO61885.1, and AIF99831.1. In summary, the results of sequence alignment and phylogenetic analysis imply that Aly1281 belongs to PL family 7.

\subsection{Expression, Purification and Biochemical Characterization of Recombinant Enzyme Aly1281}

The recombinant strain BL21(DE3)/pET28a-Aly1281 was successfully induced by IPTG to produce recombinant Aly1281, which was purified by a Ni-NTA agarose column. The recombinant enzyme yield was $2.5 \mathrm{mg}$ per liter of growth media. The theoretical molecular mass of the expressed Aly1281 was $40.65 \mathrm{kDa}$ based on the nucleic acid sequence of the enzyme. The result of SDS-PAGE (Figure 2) was consistent with the predicted theoretical molecular mass. The enzymatic activity of Aly1281 was $1.15 \mathrm{U} / \mathrm{mg}$. The purified Aly1281 was treated with thrombin to cut the His-tag and the result indicated that the enzyme activity of Aly1281 was not affected by His-tag. Therefore, the purified Aly1281 was used in further investigations of enzymatic characteristics. 


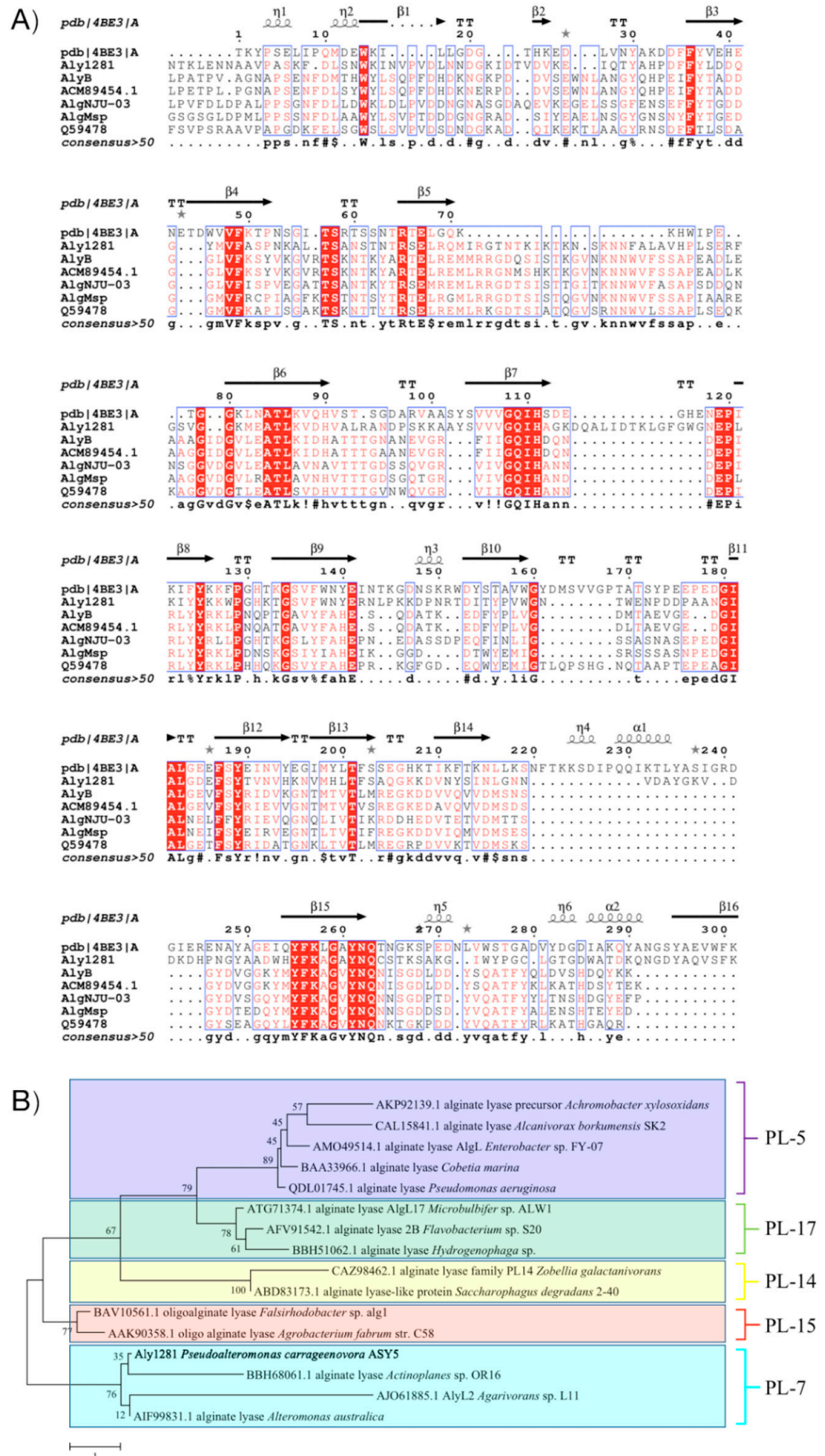

Figure 1. Multiple sequence alignment and phylogenetic analysis of A1y1281. (A) Conserved regions are highlighted with a yellow border. Residues involved in the catalytic and formation of substrate-binding pockets are indicated by green and blue triangles, respectively. (B) A phylogenetic tree was constructed by using MEGA software version 7.0 (MEGA7). Alginate lyases from families 5, 7, 14, 15, and 17 are respectively marked by purple, blue, yellow, red, and green boxes. 


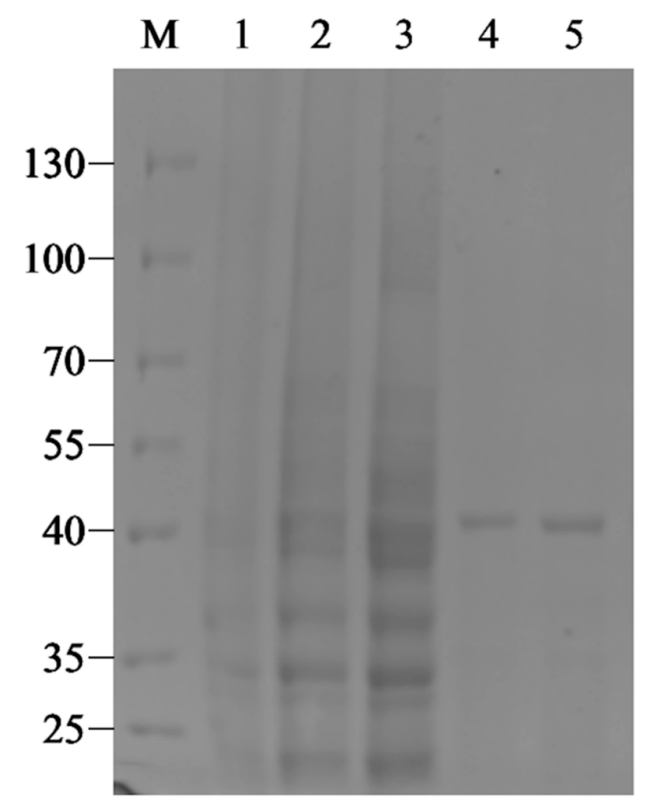

Figure 2. SDS-PAGE profiles of crude and purified Aly1281. M lane, protein marker; Lane 1, blank control expressing empty pET-28a plasmids; Lanes 2-3, crude Aly1281; Lane 4-5, purified Aly1281.

The effect of temperature on the activity of Aly1281 was shown in Figure 3A. Aly1281 exhibited maximum enzyme activity at $50{ }^{\circ} \mathrm{C}$. At the temperature range of $45-55^{\circ} \mathrm{C}$, Aly 1281 manifested over $50 \%$ of the activity observed at the optimal temperature. Few studies had reported alginate lyases that exhibited optimal reaction temperatures higher than $50^{\circ} \mathrm{C}$, such as AMOR_PL7A $\left(65^{\circ} \mathrm{C}\right)$ [22], cAlyM $\left(55^{\circ} \mathrm{C}\right)$ [23] and $\operatorname{Alg} 823\left(55^{\circ} \mathrm{C}\right)$ [5]. The thermostability of Aly 1281 was determined at a temperature ranging from $0{ }^{\circ} \mathrm{C}$ to $70{ }^{\circ} \mathrm{C}$. As shown in Figure 3B, Aly 1281 was relatively stable at temperatures lower than $55^{\circ} \mathrm{C}$. Aly 1281 showed competitive thermostability in comparison with most reported marine-derived alginate lyases [15,24-26], which could benefit its industrial application. Zhu et al. [3] characterized an extracellular biofunctional alginate lyase that retained less than $50 \%$ of the initial activity after incubation at $45^{\circ} \mathrm{C}$ for $2 \mathrm{~h}$. Li et al. [24] purified a new alginate lyase that retained less than $30 \%$ of the initial activities after incubation at $45^{\circ} \mathrm{C}$ for $2 \mathrm{~h}$.

The optimum reaction $\mathrm{pH}$ of Aly1281 was determined by assaying enzyme activities using buffers of different $\mathrm{pH}$ (4.0-10.0). As shown in Figure 3C, the optimum reaction $\mathrm{pH}$ of Aly1281 is 8.0. Aly1281 exhibited over 65\% relative activity in solutions of neutral and weakly alkaline $\mathrm{pH}(6.0-9.5)$. Aly1281 activity was nearly negligible at $\mathrm{pH}$ below 4.5, which indicates its sensitivity to acidic reaction conditions. These results are similar to those obtained from most reported marine-derived alginate lyases, which exhibit optimal $\mathrm{pH}$ at 6.0-9.0 [24,26,27]. The $\mathrm{pH}$ stability of Aly1281 was evaluated by measuring the residual activity after storing Aly1281 in buffers with different $\mathrm{pH}(4.0-10.0)$ for $24 \mathrm{~h}$ at $4{ }^{\circ} \mathrm{C}$ (Figure 3D). The Aly1281 was most stable at $\mathrm{pH}$ 8.0. Aly 1281 could retain more than $70 \%$ and $50 \%$ of the relative residual activities at $\mathrm{pH}$ ranges of 7.0 to 9.0 and 5.0 to 9.5 , respectively. 
A
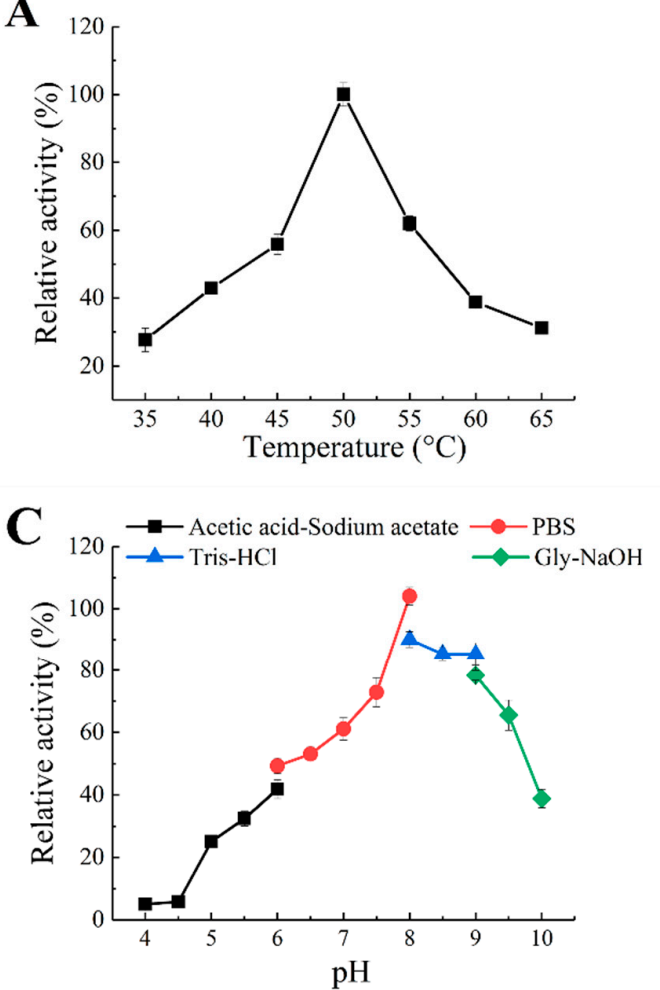

B

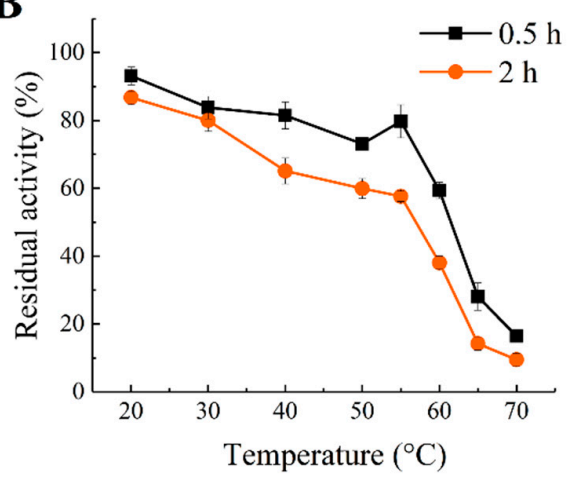

D

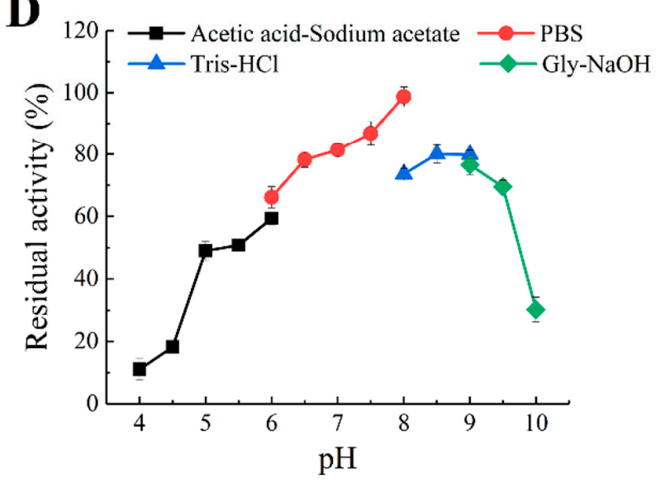

Figure 3. Effects of $\mathrm{pH}$ and temperature on the activity and stability of Aly1281. (A) Optimal temperature: Aly1281 activities were determined at various temperatures $\left(35-65{ }^{\circ} \mathrm{C}\right)$. (B) Thermal stability: The residual activities of Aly1281 were determined after incubation at various temperatures $\left(0-70{ }^{\circ} \mathrm{C}\right)$ for $30 \mathrm{~min}$ or $2 \mathrm{~h}$. Relative activity is expressed as a percentage of maximum activity under the experimental conditions. (C) $\mathrm{pH}$ optima: Aly1281 activities were determined in the acetic acid-sodium acetate buffer ( $\mathrm{pH} 4.0-6.0$ ), $\mathrm{Na}_{2} \mathrm{HPO}_{4}-\mathrm{NaH}_{2} \mathrm{PO}_{4}$ buffer ( $\mathrm{pH}$ 6.0-8.0), Tris- $\mathrm{HCl}$ buffer (8.0-9.0), and Gly-NaOH buffer (pH 9.0-10.0). (D) pH stability: The residual activities of Aly1281 were measured after the enzyme was incubated in the $\mathrm{pH}$ range of 4.0 to 10.0 with the above buffers for $24 \mathrm{~h}$ at $4{ }^{\circ} \mathrm{C}$. Data represent the mean \pm standard deviation of triplicate measurements.

\subsection{Substrate Specificity and Degradation Pattern of Aly1281}

The substrate specificity of Aly1281 was studied by using three substrates. Aly1281 possessed catalytic abilities toward all tested substrates, including alginate (100\%), polyG (134.32\%), and polyM (53.88\%). Moreover, Aly1281 exhibited higher activity toward polyG than toward polyM. Similar results have been reported for alginate lyase from Isoptericola halotolerans CGMCC5336 [9] and Microbulbifer sp. 6532A [18]. Some reported alginate lyases are only specific for polyM or polyG [6,14]. The results indicate that Aly1281 has broad substrate specificity and is a bifunctional alginate lyase that hydrolyzes both polyG and polyM.

After $12 \mathrm{~h}$ of hydrolysis, the enzymatic degradation products of Aly1281 were analyzed by using TLC and ESI-MS. As shown in Figure 4A,B, the main product of the sodium alginate hydrolysis reaction is di-alginate oligosaccharide, which indicates that Aly1281 is an endo-type alginate lyase. Compared with other alginate lyases from different sources which produced alginate oligosaccharides with broad DP, the degradation products of Aly1281 displayed highly specific degradation [15,19]. Aly510-64 from Vibrio sp. 510-64, which produces only tri-alginate oligosaccharides, exhibited a similar level of degradation specificity [28]. The high degradation specificity of Aly1281 is particularly appropriate for the preparation of AOS with high purity and could be beneficial for the production of high-value-added alginate products. 

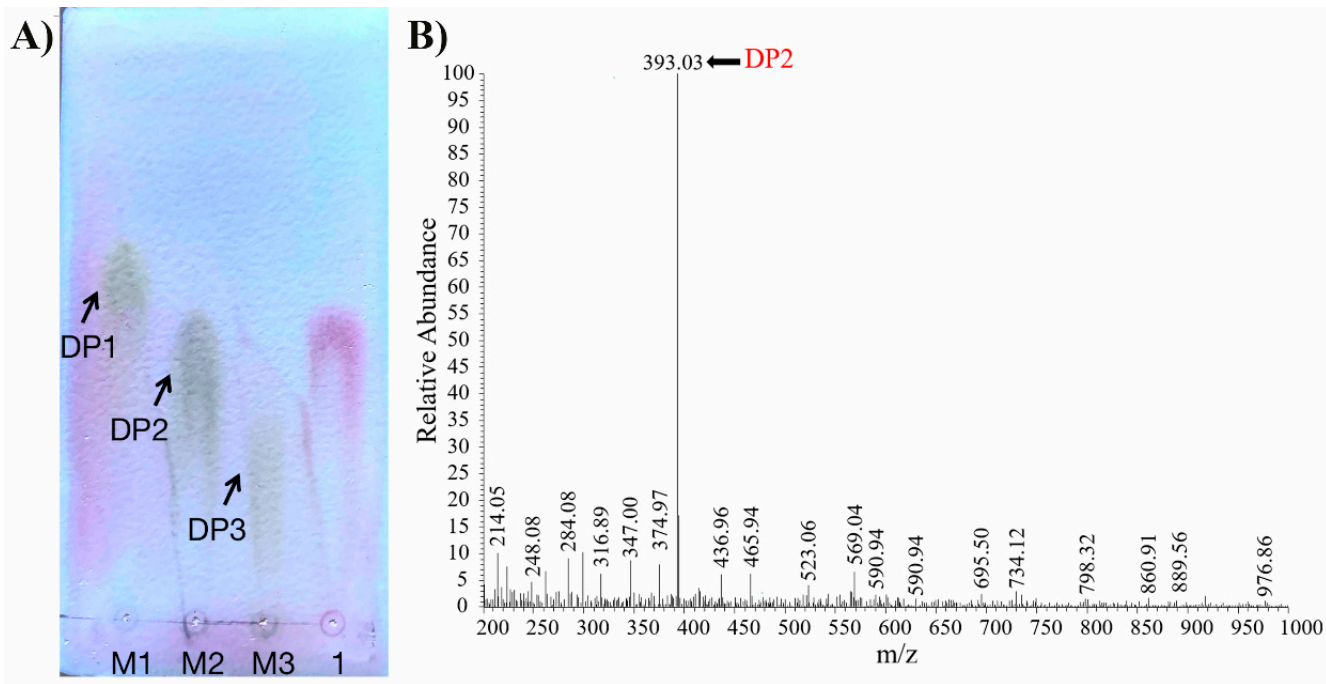

Figure 4. (A) TLC analysis of the hydrolysis products of Aly1281 with alginate sodium. Lanes 1-3 refer to the DP1-3 standards. (B) ESI-MS analysis of the hydrolysis products of Aly1281with alginate sodium.

\subsection{Antioxidant Function of the Degradation Products of Aly1281}

AOS has attracted wide attention due to its unique properties, such as anti-aggregatory [29], antioxidant [30], antitumor [31] effects, and ability to regulate blood sugar and lipids [15]. AOS reduces osteosarcoma progression and may be used as a potential drug for osteosarcoma therapy [31]. Tusi et al. [32] confirmed the neuroprotective potential of AOS against Ab-induced neural damage. Moreover, AOS has been demonstrated to render the heart resistant to I/R injury by inhibiting nitrative/oxidative stress and ER stress-mediated apoptosis [33]. These reports collectively suggest a connection between oxidative stress and apoptosis. Thus, we investigated the antioxidant effect of AOS by using various approaches, which include ferric reducing, hydroxyl radical scavenging, ABTS radical scavenging, and DPPH radical scavenging assays.

A direct correlation between antioxidant activities and reducing power has been reported [34]. $\mathrm{Fe}^{3+}$ reduction ability is an important index of electron-donating activity [35]. As shown in Figure 5A, the reducing effects of AOS increased from 0.105 to 1.16 at $700 \mathrm{~nm}$ with increasing enzyme concentration. The reducing ability of AOS is generally associated with the presence of reductones, which have been shown to exert antioxidant action by breaking free radical chains by donating a hydrogen atom [36]. The results indicate the ability of AOS to reduce ferric ions to ferrous ions.

Hydroxyl radicals were produced in vivo from water by high-energy irradiation or from $\mathrm{H}_{2} \mathrm{O}_{2}$ via a metal-catalyzed process which led to lipid peroxidation, massive protein oxidation and degradation, and DNA damage [37-40]. Most of the harmful effects of these radicals can be significantly reduced by addition of hydroxyl radical scavengers. In the present work, the hydroxyl radical scavenging activity of AOS was determined by using salicylic acid as the molecular probe. AOS exhibited a concentration-dependent ability to scavenge hydroxyl radicals and showed a maximum activity of $88.87 \% \pm 0.31 \%$ when applied at a concentration of $20.0 \mathrm{mg} / \mathrm{mL}$ (Figure 5B). Moreover, the EC50 of the hydrolysates was $8.7 \mathrm{mg} / \mathrm{mL}$, which is lower than those of other alginate oligosaccharides reported by Zhu et al. [3].

DPPH and ABTS radicals are also used as substrates to evaluate the free radical scavenging ability of an antioxidant [41]. The groups involved in H-atom transfer reactions toward DPPH and $\mathrm{ABTS}^{+}$radicals are mainly $\mathrm{C}-2$ and C-6 hydroxyls [42]. In the present work, the oligosaccharide samples were able to scavenge $\mathrm{ABTS}^{+}$and $\mathrm{DPPH}$ free radicals even at low concentrations. As shown in Figure 5C,D, $20 \mathrm{mg} / \mathrm{mL}$ AOS exhibited optimal $\mathrm{ABTS}^{+}$and DPPH radical scavenging activities of $81.50 \% \pm 0.33 \%$ and $69.65 \% \pm 1.40 \%$, respectively. The EC50 values of AOS for ABTS ${ }^{+}$and DPPH radicals were 5.65 and $7.84 \mathrm{mg} / \mathrm{mL}$, respectively, which are higher than those of the oligosaccharides 
reported in [43]. Chien et al. [44] showed that, compared with medium- or high-molecular-weight chitosan oligosaccharides, low-molecular-weight chitosan oligosaccharides exhibited higher free radical scavenging activity. The hydrolysis by Aly1281 resulted in mainly low-molecular-weight AOS (di-alginate oligosaccharide), which ensured high free radical scavenging activity.

Falkeborg et al. [40] purposed that radical scavenging activity of AOS mainly originates from a conjugated alkene acid structure. In addition, $\mathrm{Xu}$ et al. [45] purposed the catalytic mechanism of alginate lyase for the formation of the alkene acid structure based on structural and mutational analysis. In summary, the AOS obtained from Aly1281 presents good scavenging activities of up to $>88 \%$, $>81 \%$, and $>69 \%$ toward hydroxyl, ABTS, and DPPH radicals, respectively. AOS production by the enzymatic hydrolysis of Aly1281 had great potential in the high-value-added processing of marine seaweed resources.
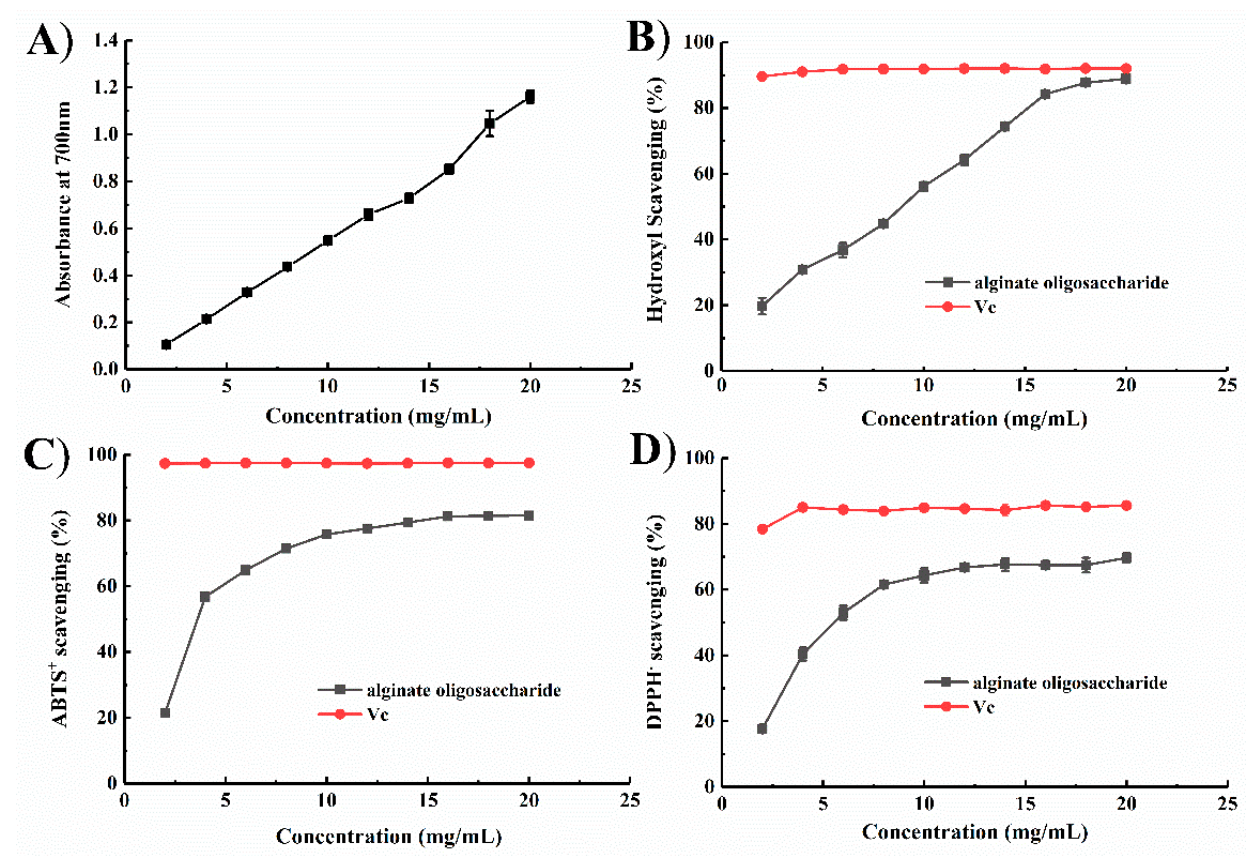

Figure 5. Antioxidant function of alginate oligosaccharides. (A) Reducing ability. (B) Scavenging effect on hydroxyl radicals. (C) Scavenging effect on ABTS radicals. (D) Scavenging effect on DPPH radicals. Data represent the mean \pm standard deviation of triplicate measurements.

\subsection{Salt Activation of Aly1281}

Due to the unique properties of the marine environment where the sourced bacteria are reproduced and evolve, enzymes extracted from marine bacteria often exhibit interesting enzymatic properties, such as salt tolerance and salt activation. The concentration effects of salts including $\mathrm{NaCl}$ and $\mathrm{KCl}$ on the enzyme activity of Aly1281 are shown in Figure 6. The enzyme activity of Aly1281 peaked after addition of $700 \mathrm{mM} \mathrm{NaCl}$ and $300 \mathrm{mM} \mathrm{KCl}$, which, respectively, increased the activity of the lyase by 4.56- and 2.77-fold compared with that without salt addition. Aly1281 activity increased sharply with addition of $\mathrm{NaCl}$ and $\mathrm{KCl}$ at concentrations lower than $300 \mathrm{mM}$. Addition of excess $\mathrm{NaCl}$ and $\mathrm{KCl}$ at concentrations higher than $300 \mathrm{mM}$ showed limited influence on enzyme activity. Moreover, addition of over $1000 \mathrm{mM}$ salt reduced enzyme activity levels to a greater extent compared with that obtained after addition of salt at low concentrations. These results indicate that the proper amount of salt could greatly promote Aly1281 activity. The catalytic efficiency of Aly1281 was highly activated by salt concentrations similar to the average salt concentration in the ocean (ca. $430 \mathrm{mM}$ ). Thus, Aly1281 could be applied in the industrial enzymatic processing of brown seaweed without water-intensive desalting [46]. 
A

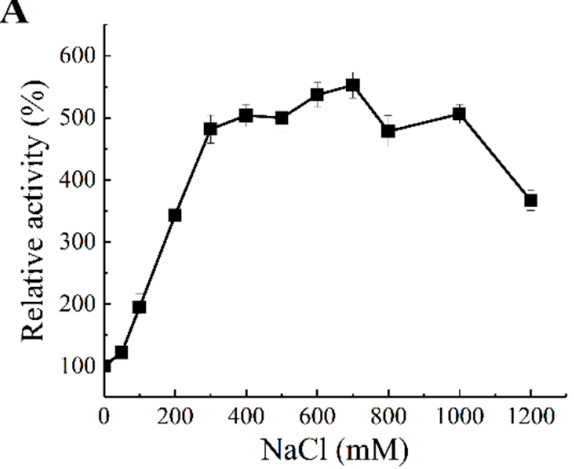

B

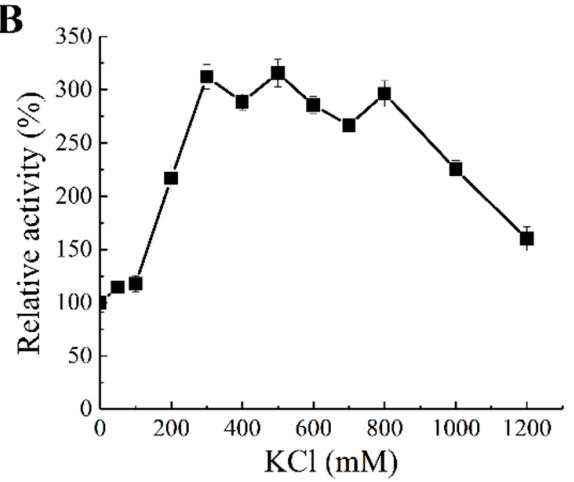

Figure 6. Effects of (A) $\mathrm{NaCl}$ and (B) $\mathrm{KCl}$ concentration on the enzymatic activity of Aly1281. Aly1281 activities were measured by using standard conditions as described in the Methods section. The activity observed without salt addition was considered to be $100 \%$ for calculations of relative activities. Each value represents the mean of three replicates \pm standard deviation. Data represent the mean \pm standard deviation of triplicate measurements.

The effect of salt addition $(300 \mathrm{mM} \mathrm{NaCl}$ and $1000 \mathrm{mM} \mathrm{KCl})$ on the kinetic parameters of Aly1281 was evaluated by using sodium alginate as a substrate (Table 1). Addition of 300 and $1000 \mathrm{mM} \mathrm{NaCl}$ decreased $K_{\mathrm{m}}$ by $54.9 \%$ and $74.3 \%$, respectively, compared with the values observed without salt addition. Similarly, addition of 300 and $1000 \mathrm{mM} \mathrm{KCl}$ decreased the $K_{\mathrm{m}}$ value by $60.3 \%$ and $76.9 \%$, respectively, relative to the no-salt case. Moreover, the $k_{\text {cat }} / K_{\mathrm{m}}$ of Aly1281 substantially increased by salt addition. When 300 and $1000 \mathrm{mM} \mathrm{NaCl}$ were added to the system, the $k_{\text {cat }} / K_{\mathrm{m}}$ of Aly1281 increased by $353 \%$ and $664 \%$, respectively, relative to the control. When 300 and $1000 \mathrm{mM} \mathrm{KCl}$ were added, the $k_{\text {cat }} / K_{\mathrm{m}}$ of Aly 1281 increased by $341 \%$ and $508 \%$, respectively, relative to the control. The observed kinetic performance of Aly1281 indicates that salt addition could greatly enhance the substrate affinity and catalytic efficiency of the lyase, which may explain the salt activation effect.

Table 1. Kinetic parameters of Aly1281 at different $\mathrm{NaCl}$ or $\mathrm{KCl}$ concentrations.

\begin{tabular}{cccc}
\hline Salt Addition & $\mathbf{K m} / \mathbf{( m g} / \mathbf{m L})$ & $\left.\mathbf{k c a t} / \mathbf{s}^{\mathbf{- 1}}\right)$ & $\mathbf{k c a t} / \mathbf{K m} /\left(\mathbf{s}^{-\mathbf{1}} \cdot \mathbf{m g}^{\mathbf{- 1}} \cdot \mathbf{m L}\right)$ \\
\hline Control & 0.7065 & 1.070 & 1.515 \\
$0.3 \mathrm{M} \mathrm{NaCl}$ & 0.3180 & 2.185 & 6.871 \\
$1.0 \mathrm{M} \mathrm{NaCl}$ & 0.1810 & 2.095 & 11.576 \\
$0.3 \mathrm{M} \mathrm{KCl}$ & 0.2805 & 1.875 & 6.685 \\
$1.0 \mathrm{M} \mathrm{KCl}$ & 0.1631 & 1.502 & 9.208 \\
\hline
\end{tabular}

Alginate lyases of difference sources exhibit different levels of salt-activation effects and optimal salt concentrations. For example, the activity of AlgNJU-03 from Vibrio sp. NJU-03 is not affected by $\mathrm{Na}^{+}$or $\mathrm{K}^{+}$[47], the activity of Algb from Vibrio sp. W13 is increased by 2.2 -fold by $0.3 \mathrm{M} \mathrm{NaCl}$ [15], and the activity of alginate lyase from Microbulbifer $s p$. ALW1 is increased by 5.1 -fold by $0.5 \mathrm{M} \mathrm{NaCl}$ [3]. Indeed, the activity of alginate lyase from Vibrio. Harveyi-28 enhanced by 24-fold by $1 \mathrm{M} \mathrm{NaCl} \mathrm{[19].}$ In the present work, the activity of Aly1281 from P. carrageenovora ASY5 increased by 5.56-fold after addition of $0.7 \mathrm{M} \mathrm{NaCl}$. According to previous halophilic mechanism studies [48-50], the divergence of salt-activation effects among alginate lyases could be related to the bacterial source, protein sequence, and structure.

\subsection{Structural Insight into the Salt-Regulated Conformational Dynamic of Aly1281}

Enzyme catalysis has been proven to be highly correlated with its conformation dynamics [51-53]. The salt-activated or -dependent properties of alginate lyase may be due to its salt-regulated conformational dynamics. A preliminary investigation of the salt activation effect of Aly1281 was conducted by using MD simulations. RMSDs in $25 \mathrm{~ns}$ MD simulations were calculated by using the 
initial structure of the lyase as a reference (Figure 7A). Aly1281 achieved stable states with average RMSDs of $\sim 4.4 \AA$ without $\mathrm{NaCl}$ and $\sim 5.3 \AA$ in the presence of $300 \mathrm{mM} \mathrm{NaCl}$. Aly1281 showed higher RMSDs in $300 \mathrm{mM} \mathrm{NaCl}$ than in the absence of $\mathrm{NaCl}$ over the entire MD simulation process. This result indicates that addition of salt increases the overall structural fluctuations of Aly1281. Similar increases in RMSD in Candida antarctica lipase B in high-concentration urea solvent have been observed [54]. The RMSFs of the MD simulations are shown in Figure 7B; here, different protein domains of Aly1281 responded differently to the addition of salt. The domain conformations could be either stabilized or flexibilized by salt addition.
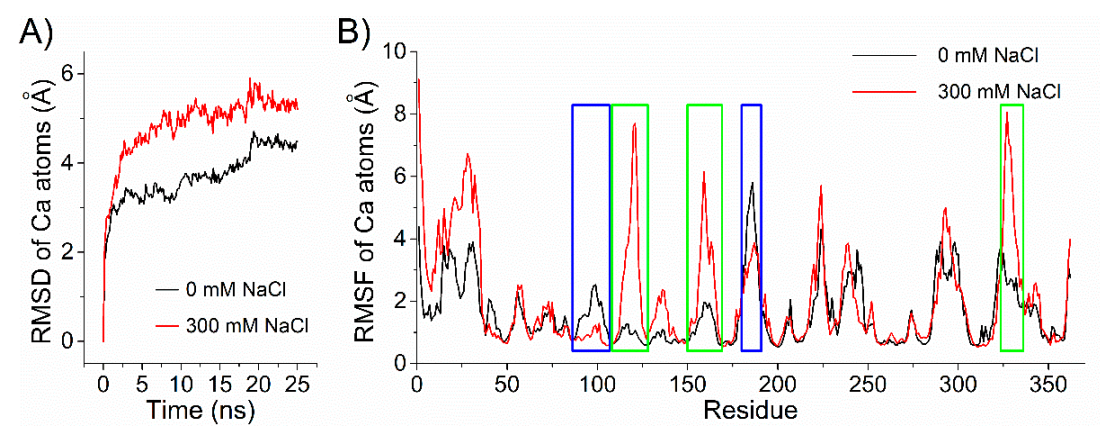

Figure 7. (A) RMSDs of alpha carbon atoms in $25 \mathrm{~ns}$ MD simulations as a function of time relative to the initial structure of Aly1281. (B) RMSFs of the alpha carbon atoms in 25 ns MD simulations of Aly1281. Blue and green boxes indicate protein domains that are highly stabilized or flexibilized by the addition of salt.

MD trajectories for Aly1281 were characterized in terms of RMSFs from the energy-minimized structure to further study potential salt-induced conformational changes. Figure 8A,B show the conformational dynamic patterns of Aly1281 in the presence of 0 and $300 \mathrm{mM} \mathrm{NaCl}$. The domains most influenced by the addition of salt showed significantly enhanced or depressed fluctuations and mainly comprised Loop_Rig1 (90SPNKALTSANSTNTRSE 106 ) and Loop_Rig2 (181ALIDTKLG 188 ), which were particularly stabilized by the addition of salt, and Loop_Flex1 (113 GTNTKIKTKNSKNN 126 ) and Loop_Flex2 (156 LRANDPSKKAA 166 and ${ }_{326}$ IWYPG $_{330}$ ), which were flexibilized by the salt solvent environment. According to a previous study on the crystal structure and catalytic mechanism of alginate lyase [21], Loop_Rig1 (90SPNKALTSANSTNTRSE ${ }_{106}$ ) and Loop_Rig2 (181 ALIDTKLG 188$)$ are lid loops located at opposite sides of the catalytic tunnel and near substrate binding sites (i.e., Q173, H175, and Y315). These lid loops are a typical structural feature of PL7 and PL18 alginate lyases and play critical roles in their catalytic reaction. A diversity study of alginate lyases, including AlyA from K. pneumoniae (PDB code 4OZX), alyPG from Corynebacterium sp. ALY-1 (PDB code 1UAI), and AlyA1 (PDB code 3ZPY) and AlyA5 (PDB code 4BE3) from Z. galactanivorans, demonstrated the possible relationship between the lid loop architecture (open or close) and cleavage functional variations (endolytic or exolytic activity) [55]. The RMSDs of Loop_Rig1 and Loop_Rig2 during the simulations were calculated using the initial structure as reference (Figure 8C,D). Loop_Rig1 achieved stable states with average RMSDs of $\sim 1.7 \AA$ without $\mathrm{NaCl}$ and $\sim 0.8 \AA$ in the presence of $300 \mathrm{mM}$ NaCl. Loop_Rig2 achieved stable states with average RMSDs of $\sim 3.5 \AA$ without $\mathrm{NaCl}$ and $\sim 1.4 \AA$ in the presence of 300 $\mathrm{mM} \mathrm{NaCl}$. These results indicate that the conformational fluctuations of these loops are stabilized by the addition of salt. Moreover, unlike the open conformation of Loop_Rig1 and Loop_Rig2 with 0 mM $\mathrm{NaCl}$, Loop_Rig1 and Loop_Rig2 appear to show a closed conformation near catalytic residues in the presence of $300 \mathrm{mM} \mathrm{NaCl}$. Considering the MD simulation results, the salt-induced conformational dynamics of lid loops may be involved in the salt-activation of Aly1281. 
A)

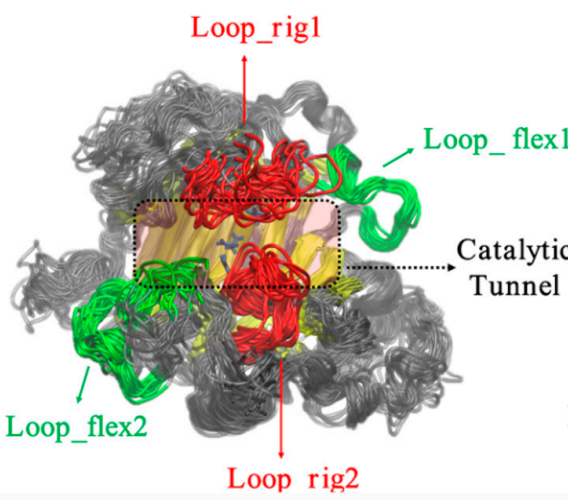

C)

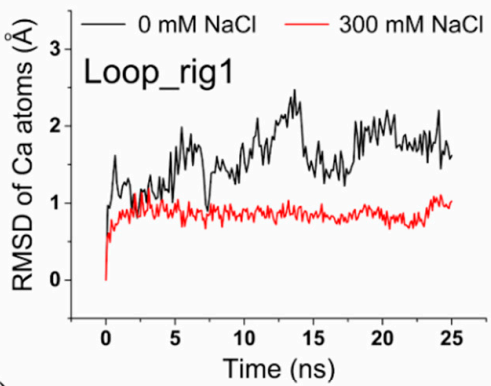

E)

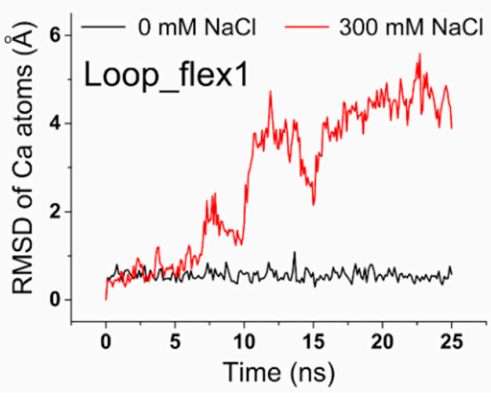

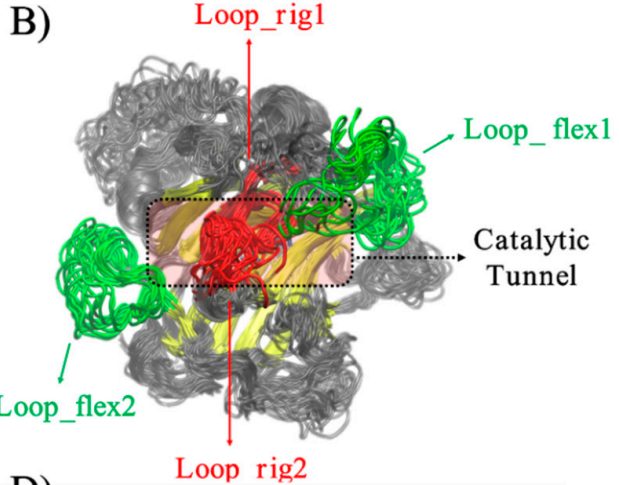

D)

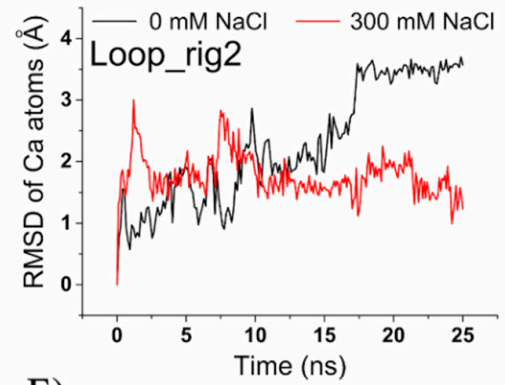

F)

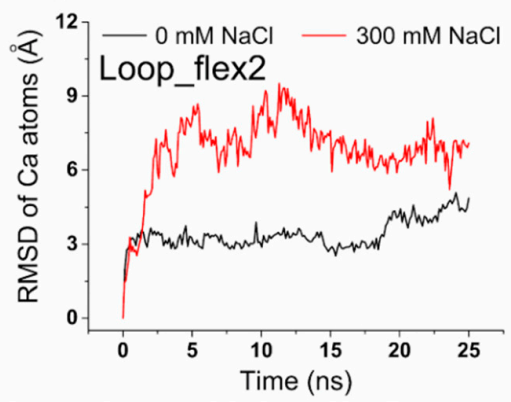

Figure 8. Conformational dynamics of Aly1281 in 25 sequential frames extracted from 25 ns MD trajectories with (A) 0 and (B) $300 \mathrm{mM} \mathrm{NaCl}$. Catalytic tunnel-forming $\beta$-sheets are shown in yellow. The catalytic residues Q173, H175, and Y315 are shown as blue sticks. Two highly stabilized regions, namely, Loop_Rig1 and Loop_Rig2, are depicted in red, and two highly flexibilized regions, namely, Loop_Flex1 and Loop_Flex2, are displayed in green. RMSDs of the alpha carbon atoms of (C) Loop_Rig1, (D) Loop_Rig2, (E) Loop_Flex1, and (F) Loop_Flex2 in 0 and $300 \mathrm{mM} \mathrm{NaCl}$ refer to the initial energy-minimized structures.

Loop_Flex1 and Loop_Flex2 of Aly1281, which are located near the gateway of the catalytic tunnel, showed increased conformational fluctuations in the presence of $300 \mathrm{mM} \mathrm{NaCl}$ (Figure $8 \mathrm{E}$, F). Loop_Flex1 achieved stable states with average RMSDs of $\sim 0.5 \AA$ without $\mathrm{NaCl}$ and $\sim 4.4 \AA$ in the presence of $300 \mathrm{mM} \mathrm{NaCl}$. Loop_Flex2 achieved stable states with average RMSDs of $\sim 4.6 \AA$ without $\mathrm{NaCl}$ and $\sim 7.0 \AA$ in the presence of $300 \mathrm{mM} \mathrm{NaCl}$. These results indicate that the conformational fluctuations of these loops are rendered flexible by the addition of salt, especially in Loop_Flex1, which showed an eightfold enhancement of RMSD. The salt-regulated flexibilization of these "entrance" loops may facilitate product release and lead to increases in catalytic efficiency. Improvements in catalytic efficiency by tunnel variation have also been observed in the rational engineering of epoxide hydrolase, where two amino acid substitutions could expand the product-release tunnel and enhance activities by 42 - and 25-fold compared with that of the wild-type enzyme [56]. Despite the significant increase in fluctuation of these loops; however, the gyration radius of Aly1281 is only slightly increased from $\sim 20.8 \AA$ (without salt) to $\sim 21.3 \AA$ (with $300 \mathrm{mM} \mathrm{NaCl}$ ) (Figure S1), which reflects a stable structural 
integrity in salt environments. In summary, the salt-activation effect of Aly1281 revealed a putative conformational dynamic feature. Future experimental validation and broader analysis of other similar enzymes will be performed to obtain an accurate understanding of the salt-activation mechanism of alginate lyase from the PL7 family.

\section{Materials and methods}

\subsection{Strains and Materials}

P. carrageenovora ASY5 (CCTCC No. CICC23819) was isolated from a mangrove (Xiamen, China) and stored in the College of Food and Biological Engineering of Jimei University. pET-28a(+) vectors, Escherichia coli DH5 $\alpha$ and BL21 (DE3) strains were purchased from TAKARA (Beijing, China). DNA polymerase, protein molecular weight markers, and polyacrylamide were purchased from TransGen Biotech (Beijing, China). Sodium alginate (Lot no. S26286), D-polymannuronic acid (polyM, Lot no. B25951) and L-polyguluronic acid (polyG, Lot no. B25962) was purchased from Yuanye Bio-Technology (Shanghai, China). Other chemicals used in this study were of analytical grade.

\subsection{Construction of Recombinant E. coli}

The Aly1281 gene from the genomic DNA of P. carrageenovora ASY5 was used to design primers for PCR amplification. The forward primer was $5^{\prime}$-CCGGAATTCAATACTAAACTGGAAAA-3' ${ }^{\prime}$, and the reverse primer was $5^{\prime}$-CCCAAGCTTCGGCTTAGTGCTCGGGC-3'. The Aly gene was obtained via PCR amplification using the genomic DNA of P. carrageenovora ASY5 as a template. The PCR products were analyzed by agarose gel electrophoresis and then purified and digested with BamHI and EcoR I. The recovered Aly gene was ligated with T4 DNA ligase to pET-28a (+) plasmids digested with the same restriction enzymes and then transformed into E. coli BL21 (DE3) competent cells for enzyme expression.

\subsection{Expression and Purification of Aly1281}

The constructed recombinant E. coli containing the Aly1281 gene was inoculated in LB medium containing $50 \mathrm{mg} / \mathrm{L}$ kanamycin at $37^{\circ} \mathrm{C}$ with horizontal shaking at $180 \mathrm{rpm}$. When the $\mathrm{OD}_{600}$ of the solution reached $0.6-0.8,0.5 \mathrm{mmol} / \mathrm{L}$ IPTG was added to induce Aly1281 expression. The cells were allowed to grow at $16{ }^{\circ} \mathrm{C}$ with horizontal shaking at $180 \mathrm{rpm}$ for $20 \mathrm{~h}$, collected via centrifugation, sonicated in lysis buffer $\left(300 \mathrm{mM} \mathrm{NaCl}, 15 \mathrm{mM}\right.$ imidazole, $\left.50 \mathrm{mM} \mathrm{NaH}{ }_{2} \mathrm{PO}_{4}\right)$, and then centrifuged at $8000 \mathrm{rpm}$ for $20 \mathrm{~min}$ at $4{ }^{\circ} \mathrm{C}$ to obtain crude Aly1281. The crude enzyme was loaded onto a Ni-NTA agarose column equilibrated with lysis buffer. The column was washed with washing buffer (300 $\mathrm{mM} \mathrm{NaCl}, 15 \mathrm{mM}$ imidazole, $50 \mathrm{mM} \mathrm{NaH} \mathrm{PO}_{4}$ ) to remove protein impurities, and the recombinant Aly1281 was eluted with elution buffer $\left(300 \mathrm{mM} \mathrm{NaCl}, 250 \mathrm{mM}\right.$ imidazole, $\left.50 \mathrm{mM} \mathrm{NaH}_{2} \mathrm{PO}_{4}\right)$. Eluted fractions with Aly activity were collected, combined and the buffer was replaced with Tris- $\mathrm{HCl}$ buffer (50 mM, pH 8.0) using a Macrosep Advance centrifugal device (Pall, East Hills, NY, USA; cut-off distance, $10 \mathrm{kDa}$ ), and then analyzed by $12 \%$ sodium dodecyl sulfate polyacrylamide gel electrophoresis (SDS-PAGE).

\subsection{Measurement of A1y1281 Activity}

Exactly $200 \mu \mathrm{L}$ of purified recombinant enzyme Aly1281 was mixed with $800 \mu \mathrm{L}$ of sodium alginate $(0.5 \%, \mathrm{pH} 8.0)$ and allowed to react at $50^{\circ} \mathrm{C}$ for $40 \mathrm{~min}$. The reaction was terminated by using a boiling water bath. Then, $1 \mathrm{~mL}$ of 3,5-dinitrosalicylate (DNS) solution was added to the solution, and the mixture was allowed to react in a boiling water bath for $10 \mathrm{~min}$. Absorbance was measured at $540 \mathrm{~nm}$. One unit of Aly1281 activity was defined as the amount of enzyme required to catalyze the production of $1 \mu \mathrm{mol}$ of reducing sugar per minute. 


\subsection{Effects of Temperature and $p H$ on Aly1281 Activity and Stability}

The activities of alginate lyase at different temperatures $\left(35-65^{\circ} \mathrm{C}\right)$ were measured to investigate the effect of temperature on Aly1281 activity; relative enzyme activities were calculated by using the activity obtained at the optimum temperature as $100 \%$. Aly1281 was incubated at different temperatures $\left(30-70{ }^{\circ} \mathrm{C}\right)$ for $2 \mathrm{~h}$ to investigate the effect of temperature on Aly1281 stability; here, residual enzyme activities were measured under the assay conditions described previously and calculated by using the initial activity as $100 \%$.

Alginate lyase activities in different buffers, including acetic acid-sodium acetate buffer $(50 \mathrm{mM}$, $\mathrm{pH} 4.0-6.0), \mathrm{Na}_{2} \mathrm{HPO}_{4}-\mathrm{NaH}_{2} \mathrm{PO}_{4}$ buffer (50 mM, pH 6.0-8.0), Tris- $\mathrm{HCl}$ buffer (50 mM, pH 8.0-9.0), and glycine-sodium hydroxide buffer (50 mM, pH 9.0-10.0), were measured under the assay conditions described previously to investigate the effect of $\mathrm{pH}$ on Aly1281 activity; here, relative enzyme activities were calculated by using the activity obtained at the optimum $\mathrm{pH}$ as $100 \%$. Aly 1281 was incubated in the buffers described above ( $50 \mathrm{mM}, \mathrm{pH} 4.0-10.0)$ at $4{ }^{\circ} \mathrm{C}$ for $24 \mathrm{~h}$ to investigate the effect of $\mathrm{pH}$ on Aly1281 stability; here, residual enzyme activities were measured under the assay conditions described previously and calculated by using the highest residual activity as $100 \%$.

\subsection{Effects of Salts on the Activity and Kinetic Parameters of Aly1281}

The effects of salts on Aly1281 activity were measured under the assay conditions described previously with different concentrations of $\mathrm{NaCl}$ or $\mathrm{KCl}(0-1200 \mathrm{mM})$; relative enzyme activities were calculated by using the activity obtained without salts as $100 \%$. The kinetic parameters of the purified Aly1281 at various salt concentrations were studied by assaying the enzyme activity of sodium alginate in different salt concentrations $(0.5-5 \mathrm{mg} / \mathrm{mL})$. The Lineweaver-Burk method was applied to calculate $K_{\mathrm{m}}$ and $k_{\text {cat }}$.

\subsection{Substrate Specificity of Aly1281}

The substrate specificity of purified Aly1281 was investigated by measuring its activity under the assay conditions described previously with $2 \mathrm{mg} / \mathrm{mL}$ sodium alginate, D-polymannuronic acid (polyM) and L-polyguluronic acid (polyG) as substrates.

\subsection{TLC and ESI-MS Analysis of the Degradation Products of Aly1281}

Exactly $200 \mu \mathrm{L}$ of purified enzyme was added to $800 \mu \mathrm{L}$ of the substrate solution $(5 \mathrm{mg} / \mathrm{mL}$ sodium alginate) to enable the degradation reaction of Aly1281. The degradation reaction was conducted at $50{ }^{\circ} \mathrm{C}$ for $12 \mathrm{~h}$, and the reducing sugar content in the reaction mixture was determined periodically. When a stable reducing sugar content was achieved, the reaction mixture was boiled for $10 \mathrm{~min}$ and centrifuged at 12,000 rpm for $10 \mathrm{~min}$. Absolute ethanol was then added to the supernatant to a final concentration of $75 \%(\mathrm{v} / \mathrm{v})$, and the mixture was incubated at $4{ }^{\circ} \mathrm{C}$ for $2 \mathrm{~h}$. After incubation, the supernatant was concentrated by rotary evaporation and lyophilized.

The degradation products of Aly 1281 were analyzed by using TLC with a solvent of $n$-butyl alcohol-acetic acid-water (2:2:1). Visualization of the products was achieved by spraying the TLC plate with $10 \%(\mathrm{v} / \mathrm{v}) \mathrm{H}_{2} \mathrm{SO}_{4}$ in alcohol and then heating at $120^{\circ} \mathrm{C}$ for $5 \mathrm{~min}$.

The composition and DP of the products were further determined via electrospray ionization mass spectrometry (ESI-MS). A total of $2 \mu \mathrm{L}$ of the degradation products was loop-injected into the ESI-MS instrument (Bruker Esquire HCT, USA) operated in negative-ion mode with the following settings: calibration dynamics, 2; capillary voltage, $4.00 \mathrm{kV}$; cone voltage, $20.00 \mathrm{~V}$; source temperature, $150{ }^{\circ} \mathrm{C}$; desolvation temperature, $350^{\circ} \mathrm{C}$; cone gas flow rate, $50 \mathrm{~L} / \mathrm{h}$; and desolvation gas flow, $500 \mathrm{~L} / \mathrm{h}$. 


\subsection{Antioxidant Function of the Alginate Degradation Products of Aly1281}

\subsubsection{Ferric Reducing Power}

Ferric reducing power was determined in accordance with a previously described method [57] with slight modifications. Briefly, $300 \mu \mathrm{L}$ of degradation products of different concentrations was mixed with $350 \mu \mathrm{L}$ of $0.2 \mathrm{M}$ sodium phosphate buffer $(\mathrm{pH} 7.0)$ and $350 \mu \mathrm{L}\left(1 \%\right.$, w/v) of $\left[\mathrm{K}_{3} \mathrm{Fe}(\mathrm{CN})_{6}\right]$. After $20 \mathrm{~min}$ of incubation at $50{ }^{\circ} \mathrm{C}$, the mixture was added to a mixture of $350 \mu \mathrm{L}(10 \%$, w/v) of trichloroacetic acid and $150 \mu \mathrm{L}(1 \%, \mathrm{w} / \mathrm{v})$ of $\mathrm{FeCl}_{3}(0.1 \%)$. The absorbance of the mixture was measured at $700 \mathrm{~nm}$ by using a UV spectrophotometer. Distilled water was used as the blank.

\subsubsection{Scavenging Activity of Hydroxyl Radical}

Hydroxyl radical scavenging activity was determined in accordance with a previously described method [5]. Briefly, $0.1 \mathrm{~mL}$ of $\mathrm{FeSO}_{4}(9.0 \mathrm{mM}), 0.6 \mathrm{~mL}$ of deionized water, $2 \mathrm{~mL}$ of oligosaccharide solution, $0.1 \mathrm{~mL}$ of $\mathrm{H}_{2} \mathrm{O}_{2}(8.8 \mathrm{mM})$, and $0.1 \mathrm{~mL}$ of ethanol salicylate $(9.0 \mathrm{mM})$ were mixed and incubated at $37^{\circ} \mathrm{C}$ for $30 \mathrm{~min}$. The absorbance of the mixture was then determined at $510 \mathrm{~nm}$. Distilled water and Vc were used as the blank and positive control, respectively. Scavenging activity (\%) was calculated by using the following equation:

$$
\text { Hydroxyl free-radical scavenging activity }(\%)=\left(\mathrm{A}_{0}-\mathrm{A}_{\text {sample }}\right) / \mathrm{A}_{0} \times 100 \text {, }
$$

where $A_{0}$ and $A_{\text {sample }}$ are the absorbance of the blank and final absorbance of each sample at $510 \mathrm{~nm}$, respectively.

\subsubsection{Scavenging Activity of 2,2-Diphenyl-1-picrylhydrazyl (DPPH)}

DPPH radical-scavenging activity was determined by using a previous method with minor modifications [58]. Oligosaccharide solutions $(500 \mu \mathrm{L})$ of different concentrations were mixed with DPPH reagent $(500 \mu \mathrm{L})$ and then incubated in the dark at room temperature for $30 \mathrm{~min}$. The absorbance of the mixture was determined at $517 \mathrm{~nm}$. Distilled water was set as the blank, and Vc was used as the positive control. The scavenging activity (\%) of DPPH was calculated by using the following equation:

$$
\mathrm{DPPH} \text { radical scavenging activity }(\%)=\left(\mathrm{A}_{0}-\mathrm{A}_{\text {sample }}\right) / \mathrm{A}_{0} \times 100 \text {, }
$$

where $A_{0}$ and $A_{\text {sample }}$ are the absorbance of the blank and final absorbance of each sample at 517 $\mathrm{nm}$, respectively.

\subsubsection{Scavenging Activity of 2,2'-Azinobis-(3-ethylbenzthiazoline-6-sulphonate) (ABTS)}

ABTS radical-scavenging activity was determined according to a previous method with minor modifications [59]. ABTS $(7 \mathrm{mM})$ and $\mathrm{K}_{2} \mathrm{~S}_{2} \mathrm{O}_{8}(2.45 \mathrm{mM})$ solutions were mixed at equal volumes and stored in the dark for $16 \mathrm{~h}$ to produce ABTS radicals $\left(\mathrm{ABTS}^{+}\right)$. The mixture was diluted with $\mathrm{PBS}(\mathrm{pH}$ 7.0) to an absorbance of $A_{734 \mathrm{~nm}}=0.700 \pm 0.020$. Then, $0.1 \mathrm{~mL}$ of oligosaccharide solution and $1 \mathrm{~mL}$ of ABTS solution were mixed and incubated at $37^{\circ} \mathrm{C}$ for $15 \mathrm{~min}$. The absorbance of this solution was measured at $734 \mathrm{~nm}$. Distilled water was set as the blank, and Vc was used as the positive control. The scavenging activity (\%) of ABTS was calculated by using the following equation:

$$
\text { ABTS radical scavenging activity }(\%)=\left(\mathrm{A}_{0}-\mathrm{A}_{\text {sample }}\right) / \mathrm{A}_{0} \times 100,
$$

where $\mathrm{A}_{0}$ and $\mathrm{A}_{\text {sample }}$ are the absorbance of the blank and final absorbance of each sample at 734 nm, respectively. 


\subsection{Comparative Study by MD Simulation}

Modeling of the 3D structure of Aly1281 was conducted by using the web-based I-TASSER server (http://zhanglab.ccmb.med.umich.edu/I-TASSER) using AlyB from Vibrio splendidus (PDB ID: 5zu5), alginate lyase from Klebsiella pneumoniae (PDB ID: 4ozx), and AlyA5 from Zobellia galactanivorans (PDB ID: 4be3) as threading templates [60]. MD simulations were performed to investigate the salt-induced conformational dynamics of Aly1281 and conducted by using the NAMD 2.13 simulation software package. The CHARMM36 force field was used. The TIP3P water model was used for solvent molecular modeling. $\mathrm{Na}^{+}$and $\mathrm{Cl}^{-}$were used to neutralize charges in the simulation system and added to the required concentration for $\mathrm{NaCl}$ simulation. The particle mesh Ewald algorithm was used to calculate long-range electrostatic interactions with cutoff distances of $12 \AA$ for non-bonding interactions and $10 \AA$ for switching distances. The MD simulations were performed under NPT conditions using Langevin dynamics and the Langevin piston method to maintain a constant pressure and temperature. Hydrogen atoms between proteins and water molecules were kept rigid by using the RATTLE and SETTLE algorithms. Simulations were carried out at a $2 \mathrm{fs}$ timestep, and coordinates were saved at $10 \mathrm{ps}$ intervals. Each simulation system was first minimized to relax high-energy contact with 15,000 energy minimization steps at $50 \mathrm{~K}$ followed by $25 \mathrm{~ns}$ simulations in the presence of 0 or $0.3 \mathrm{M} \mathrm{NaCl}$ at $323.15 \mathrm{~K}$. Simulation trajectories were generated, and physical parameters, including root-mean-squared deviation (RMSD), root-mean-square fluctuation (RMSF) and radius of gyration were calculated by using VMD. Protein structure images were obtained by VMD.

\section{Conclusions}

In the present research, we describe the characterization of the novel PL7 alginate lyase Aly1281 from the marine bacterium P. carrageenovora ASY5. Aly1281 showed maximum activity at $50{ }^{\circ} \mathrm{C}$ and $\mathrm{pH}$ 8.0. The enzyme has broad substrate specificity and could endolytically cleave alginate. Aly1281 exhibited high degradation specificity toward sodium alginate and mainly produced di-alginate oligosaccharides. The degradation products of Aly1281 exhibited good antioxidant activity, thus indicating the potential applications of this lyase in the food industry. A putative conformational structural feature was proposed by MD simulation analysis to better understand the salt-activation effect of Aly1281. Future work will focus on the determination of the 3D structure of the lyase under different salt concentrations to enable the broader analysis of other similar enzymes and accurate elucidation of the salt-activation mechanism of Aly1281.

Supplementary Materials: The following are available online at http://www.mdpi.com/1660-3397/18/2/95/s1, Figure S1: The radius of gyration of Aly1281 during $25 \mathrm{~ns}$ MD simulation as a function of time.

Author Contributions: Y.-H.Z. and A.-F.X. designed the experiments. Y.S., C.J., Q.-M.Y., and H.-F.W. conducted the experiments. Y.-H.Z., Y.S. and A.-F.X. analyzed the data. Y.-H.Z., C.J., and A.-F.X. wrote the main manuscript. All authors reviewed the manuscript. All authors have read and agreed to the published version of the manuscript.

Funding: This work was supported by Projects of Science and Technology Program of Xiamen City (3502Z20183030), Projects of university-enterprise cooperation of Fujian province (2016N5008) and Research Startup Funding of Jimei University (ZQ2019005).

Conflicts of Interest: The authors declare no competing financial interest.

\section{References}

1. Tanna, B.; Mishra, A. Nutraceutical Potential of Seaweed Polysaccharides: Structure, Bioactivity, Safety, and Toxicity. Compr. Rev. Food. Sci. F 2019, 18, 817-831. [CrossRef]

2. Zhu, B.; Hu, F.; Yuan, H.; Sun, Y.; Yao, Z. Biochemical Characterization and Degradation Pattern of a Unique pH-Stable PolyM-Specific Alginate Lyase from Newly Isolated Serratia marcescens NJ-07. Mar. Drugs 2018, 16, 129. [CrossRef]

3. Zhu, Y.; Wu, L.; Chen, Y.; Ni, H.; Xiao, A.; Cai, H. Characterization of an extracellular biofunctional alginate lyase from marine Microbulbifer sp. ALW1 and antioxidant activity of enzymatic hydrolysates. Microbiol. Res. 2016, 182, 49-58. [CrossRef] 
4. Zhu, B.; Ni, F.; Sun, Y.; Yao, Z. Expression and characterization of a new heat-stable endo-type alginate lyase from deep-sea bacterium Flammeovirga sp. NJ-04. Extremophiles 2017, 21, 1027-1036. [CrossRef]

5. Zeng, J.; An, D.; Jiao, C.; Xiao, Q.; Weng, H.; Yang, Q.; Xiao, A. Cloning, expression, and characterization of a new $\mathrm{pH}$ - and heat-stable alginate lyase from Pseudoalteromonas carrageenovora ASY5. J. Food Biochem. 2019, 43, e12886. [CrossRef]

6. Huang, L.; Zhou, J.; Li, X.; Peng, Q.; Lu, H.; Du, Y. Characterization of a new alginate lyase from newly isolated Flavobacterium sp. S20. J. Ind. Microbiol. Biotechnol. 2013, 40, 113-122. [CrossRef]

7. Kawada, A.; Hiura, N.; Shiraiwa, M.; Tajima, S.; Hiruma, M.; Hara, K.; Ishibashi, A.; Takahara, H. Stimulation of human keratinocyte growth by alginate oligosaccharides, a possible co-factor for epidermal growth factor in cell culture. Febs Lett. 1997, 408, 43-46. [CrossRef]

8. Kumar, G.P.; Sudheesh, S.; Vijayalakshmi, N.R. Hypoglycaemic effect of Coccinia indica: Mechanism of action. Planta Med. 1993, 59, 330-332. [CrossRef]

9. Dou, W.; Wei, D.; Li, H.; Li, H.; Rahman, M.M.; Shi, J.; Xu, Z.; Ma, Y. Purification and characterisation of a bifunctional alginate lyase from novel Isoptericola halotolerans CGMCC 5336. Carbohyd. Polym. 2013, 98, 1476-1482. [CrossRef]

10. Liu, H.Y.; Geng, M.Y.; Xin, X.L.; Li, F.C.; Zhang, Z.Q.; Li, J.; Ding, J. Multiple and multivalent interactions of novel anti-AIDS drug candidates, sulfated polymannuronate (SPMG)-derived oligosaccharides, with gp120 and their anti-HIV activities. Glycobiology 2005, 15, 501-510. [CrossRef]

11. Wang, Y.; Han, F.; Hu, B.; Li, J.; Yu, W. In vivo prebiotic properties of alginate oligosaccharides prepared through enzymatic hydrolysis of alginate. Nutr. Res. 2006, 26, 597-603. [CrossRef]

12. Cherry, P.; Yadav, S.; Strain, C.R.; Allsopp, P.J.; McSorley, E.M.; Ross, R.P.; Stanton, C. Prebiotics from Seaweeds: An Ocean of Opportunity? Mar. Drugs 2019, 17, 327. [CrossRef] [PubMed]

13. LINKER, A.; MAYER, K. Production of unsaturated uronides by bacterial hyaluronidases. Nature 1954, 174, 1192-1193. [CrossRef]

14. Cao, L.; Xie, L.; Xue, X.; Tan, H.; Liu, Y.; Zhou, S. Purification and characterization of alginate lyase from Streptomyces species strain A5 isolated from banana rhizosphere. J. Agr. Food Chem. 2007, 55, 5113-5117. [CrossRef]

15. Zhu, B.; Tan, H.; Qin, Y.; Xu, Q.; Du, Y.; Yin, H. Characterization of a new endo-type alginate lyase from Vibrio sp. W13. Int. J. Biol. Macromol. 2015, 75, 330-337. [CrossRef]

16. Zhu, B.; Yin, H. Alginate lyase: Review of major sources and classification, properties, structure-function analysis and applications. Bioengineered 2015, 6, 125-131. [CrossRef]

17. Zhu, B.; Ni, F.; Sun, Y.; Ning, L.; Yao, Z. Elucidation of degrading pattern and substrate recognition of a novel bifunctional alginate lyase from Flammeovirga sp. NJ-04 and its use for preparation alginate oligosaccharides. Biotechnol. Biofuels 2019, 12, 1-13. [CrossRef]

18. Swift, S.M.; Hudgens, J.W.; Heselpoth, R.D.; Bales, P.M.; Nelson, D.C. Characterization of AlgMsp, an Alginate Lyase from Microbulbifer sp. 6532A. Plos One 2014, 9, 11. [CrossRef]

19. Kitamikado, M.; Tseng, C.H.; Yamaguchi, K.; Nakamura, T. Two types of bacterial alginate lyases. Appl. Environ. Microbiol. 1992, 58, 2474-2478. [CrossRef]

20. Chen, X.L.; Dong, S.; Xu, F.; Dong, F.; Li, P.Y.; Zhang, X.Y.; Zhou, B.C.; Zhang, Y.Z.; Xie, B.B. Characterization of a New Cold-Adapted and Salt-Activated Polysaccharide Lyase Family 7 Alginate Lyase from Pseudoalteromonas sp. SM0524. Front Microbiol. 2016, 7, 1120. [CrossRef]

21. Fran Ois, T.; Lundqvist, L.C.E.; Murielle, J.; Alexandra, J.; Tristan, B.; Corine, S.M.; Gurvan, M.; Mirjam, C. Comparative characterization of two marine alginate lyases from Zobellia galactanivorans reveals distinct modes of action and exquisite adaptation to their natural substrate. J. Biol. Chem. 2013, 288, 23021-23037.

22. Vuoristo, K.S.; Fredriksen, L.; Oftebro, M.; Arntzen, M.Ø.; Aarstad, O.A.; Stokke, R.; Steen, I.H.; Hansen, L.D.; Schüller, R.B.; Aachmann, F.L. Production, characterization and application of an alginate lyase, AMOR_PL7A, from hot vents in the Arctic Mid-Ocean Ridge. J. Agr. Food Chem. 2019, 67, 2936-2945. [CrossRef] [PubMed]

23. Yang, M.; Yang, S.; Liu, Z.; Li, N.; Li, L.; Mou, H. Rational Design of Alginate Lyase from Microbulbifer sp. Q7 to Improve Thermal Stability. Mar. Drugs 2019, 17, 378. [CrossRef]

24. Li, S.; Wang, L.; Hao, J.; Xing, M.; Sun, J.; Sun, M. Purification and Characterization of a New Alginate Lyase from Marine Bacterium Vibrio sp. SY08. Mar. Drugs 2017, 15, 1. [CrossRef] 
25. Zhu, B.; Ning, L.; Jiang, Y.; Ge, L. Biochemical Characterization and Degradation Pattern of a Novel Endo-Type Bifunctional Alginate Lyase AlyA from Marine Bacterium Isoptericola halotolerans. Mar. Drugs 2018, 16, 258. [CrossRef]

26. Li, J.W.; Dong, S.; Song, J.; Li, C.B.; Chen, X.L.; Xie, B.B.; Zhang, Y.Z. Purification and Characterization of a Bifunctional Alginate Lyase from Pseudoalteromonas sp. SM0524. Mar. Drugs 2011, 9, 109-123. [CrossRef]

27. Zhu, B.; Huang, L.; Tan, H.; Qin, Y.; Du, Y.; Yin, H. Characterization of a new endo-type polyM-specific alginate lyase from Pseudomonas sp. Biotechnol. Lett. 2015, 37, 409-415. [CrossRef]

28. Hu, X.; Jiang, X.; Hwang, H. Purification and Characterization of an Alginate Lyase from Marine Bacterium Vibrio sp. Mutant Strain 510-64. Curr. Microbiol. 2006, 53, 135-140. [CrossRef]

29. Rezaii, N.; Khodagholi, F. Evaluation of chaperone-like activity of alginate: Microcapsule and water-soluble forms. Protein J. 2009, 28, 124-130. [CrossRef]

30. Jeon, T.I.; Hwang, S.G.; Park, N.G.; Jung, Y.R.; Shin, S.I.; Choi, S.D.; Park, D.K. Antioxidative effect of chitosan on chronic carbon tetrachloride induced hepatic injury in rats. Toxicology 2003, 187, 67-73. [CrossRef]

31. Chen, J.; Yu, H.; Lirong, Z.; Yingjian, W.; Shichao, W.; Yanzi, Z.; Haiyan, G.; Degang, J.; Yingtao, W. Alginate Oligosaccharide DP5 Exhibits Antitumor Effects in Osteosarcoma Patients following Surgery. Front Pharmacol. 2017, 8, 623. [CrossRef] [PubMed]

32. Tusi, S.K.; Khalaj, L.; Ashabi, G.; Kiaei, M.; Khodagholi, F. Alginate oligosaccharide protects against endoplasmic reticulum- and mitochondrial-mediated apoptotic cell death and oxidative stress. Biomaterials 2011, 32, 5438-5458. [CrossRef] [PubMed]

33. Guo, J.; Xu, F.; Li, Y.; Li, J.; Liu, X.; Wang, X.; Hu, L.; An, Y. Alginate oligosaccharide alleviates myocardial reperfusion injury by inhibiting nitrative and oxidative stress and endoplasmic reticulum stress-mediated apoptosis. Drug Design Develop. Ther. 2017, 11, 2387-2397. [CrossRef] [PubMed]

34. Liu, J.; Xu, Q.; Zhang, J.; Zhou, X.; Lyu, F.; Zhao, P.; Ding, Y. Preparation, composition analysis and antioxidant activities of konjac oligo-glucomannan. Carbohyd Polym 2015, 130, 398-404. [CrossRef] [PubMed]

35. Dorman, H.J.D.; Peltoketo, A.; Hiltunen, R.; Tikkanen, M.J. Characterisation of the antioxidant properties of de-odourised aqueous extracts from selected Lamiaceae herbs. Food Chem. 2003, 83, 255-262. [CrossRef]

36. Huang, D.; Ou, B.; Prior, R.L. The Chemistry behind Antioxidant Capacity Assays. J Agr. Food Chem. 2005, 53, 1841-1856. [CrossRef] [PubMed]

37. Wang, P.; Jiang, X.; Jiang, Y.; Hu, X.; Mou, H.; Li, M.; Guan, H. In vitro antioxidative activities of three marine oligosaccharides. Nat. Prod. Res. 2007, 21, 646-654. [CrossRef] [PubMed]

38. Li, J.; Xiao, Q.; Huang, Y.; Ni, H.; Wu, C.; Xiao, A. Tannase application in secondary enzymatic processing of inferior Tieguanyin oolong tea. Electron. J. Biotechnol. 2017, 28, 87-94. [CrossRef]

39. Kataki, M.S.; Kakoti, B.B.; Bhuyan, B.; Rajkumari, A.; Rajak, P. Garden rue inhibits the arachidonic acid pathway, scavenges free radicals, and elevates FRAP: Role in inflammation. Chin. J. Nat. Med. 2014, 12, 172-179. [CrossRef]

40. Falkeborg, M.; Cheong, L.; Gianfico, C.; Sztukiel, K.M.; Kristensen, K.; Glasius, M.; Xu, X.; Guo, Z. Alginate oligosaccharides: Enzymatic preparation and antioxidant property evaluation. Food Chem. 2014, 164, 185-194. [CrossRef]

41. Borazjani, N.J.; Tabarsa, M.; You, S.; Rezaei, M. Effects of extraction methods on molecular characteristics, antioxidant properties and immunomodulation of alginates from Sargassum angustifolium. Int. J. Biol. Macromol. 2017, 101, 703-711. [CrossRef]

42. Tsao, R. Chemistry and Biochemistry of Dietary Polyphenols. Nutrients 2010, 2, 1231-1246. [CrossRef]

43. Kang, O.L.; Ghani, M.; Hassan, O.; Rahmati, S.; Ramli, N. Novel agaro-oligosaccharide production through enzymatic hydrolysis: Physicochemical properties and antioxidant activities. Food Hydrocolloid 2014, 42, 304-308. [CrossRef]

44. Chien, P.; Sheu, F.; Huang, W.; Su, M. Effect of molecular weight of chitosans on their antioxidative activities in apple juice. Food Chem. 2007, 102, 1192-1198. [CrossRef]

45. Xu, F.; Dong, F.; Wang, P.; Cao, H.; Li, C.; Li, P.; Pang, X.; Zhang, Y.; Chen, X. Novel Molecular Insights into the Catalytic Mechanism of Marine Bacterial Alginate Lyase AlyGC from Polysaccharide Lyase Family 6. J. Biol. Chem. 2017, 292, 4457-4468. [CrossRef]

46. Doshi, A.; Pascoe, S.; Coglan, L.; Rainey, T.J. Economic and policy issues in the production of algae-based biofuels: A review. Renew Sust. Energ. Rev. 2016, 64, 329-337. [CrossRef] 
47. Zhu, B.; Sun, Y.; Ni, F.; Ning, L.; Yao, Z. Characterization of a new endo-type alginate lyase from Vibrio sp. NJU-03. Int. J. Biol. Macromol. 2018, 108, 1140-1147. [CrossRef]

48. Graziano, G.; Merlino, A. Molecular bases of protein halotolerance. Bba-Proteins Proteom 2014, 1844, 850-858. [CrossRef]

49. Li, P.; Zhang, Y.; Xie, B.; Zhang, Y.; Hao, J.; Wang, Y.; Wang, P.; Li, C.; Qin, Q.; Zhang, X.; et al. Structural and Mechanistic Insights into the Improvement of the Halotolerance of a Marine Microbial Esterase by Increasing Intra- and Interdomain Hydrophobic Interactions. Appl. Environ. Microb. 2017, 83, e01286-17. [CrossRef]

50. Tadeo, X.; Lopez-Mendez, B.; Trigueros, T.; Lain, A.; Castano, D.; Millet, O. Structural Basis for the Aminoacid Composition of Proteins from Halophilic Archea. Plos Biol. 2009, 7, 12. [CrossRef]

51. Entsch, B.; Cole, L.J.; Ballou, D.P. Protein dynamics and electrostatics in the function of p-hydroxybenzoate hydroxylase. Arch Biochem Biophys 2005, 433, 297-311. [CrossRef] [PubMed]

52. Ballou, D.P.; Entsch, B.; Cole, L.J. Dynamics involved in catalysis by single-component and two-component flavin-dependent aromatic hydroxylases. Biochem. Bioph. Res. Co. 2005, 338, 590-598. [CrossRef]

53. Thompson, M.C.; Barad, B.A.; Wolff, A.M.; Sun Cho, H.; Schotte, F.; Schwarz, D.M.C.; Anfinrud, P.; Fraser, J.S. Temperature-jump solution $X$-ray scattering reveals distinct motions in a dynamic enzyme. Nat. Chem. 2019, 11, 1058-1066. [CrossRef]

54. Monhemi, H.; Housaindokht, M.R.; Moosavi-Movahedi, A.A.; Bozorgmehr, M.R. How a protein can remain stable in a solvent with high content of urea: Insights from molecular dynamics simulation of Candida antarctica lipase B in urea: Choline chloride deep eutectic solvent. Phys. Chem. Chem. Phys. 2014, 16, 14882-14893. [CrossRef] [PubMed]

55. Xu, F.; Wang, P.; Zhang, Y.; Chen, X. Diversity of Three-Dimensional Structures and Catalytic Mechanisms of Alginate Lyases. Appl. Environ. Microb. 2018, 84, e02040-17. [CrossRef]

56. Kong, X.; Yuan, S.; Li, L.; Chen, S.; Xu, J.; Zhou, J. Engineering of an epoxide hydrolase for efficient bioresolution of bulky pharmaco substrates. P Natl. Acad. Sci. USA 2014, 111, 15717-15722. [CrossRef]

57. Gülçin, İ; Bursal, E.; Şehitoğlu, M.H.; Bilsel, M.; Gören, A.C. Polyphenol contents and antioxidant activity of lyophilized aqueous extract of propolis from Erzurum, Turkey. Food Chem. Toxicol. 2010, 48, 2227-2238. [CrossRef]

58. Alashi, A.M.; Blanchard, C.L.; Mailer, R.J.; Agboola, S.O.; Mawson, A.J.; He, R.; Girgih, A.; Aluko, R.E. Antioxidant properties of Australian canola meal protein hydrolysates. Food Chem. 2014, 146, 500-506. [CrossRef]

59. Arul Ananth, D.; Sivasudha, T.; Rameshkumar, A.; Jeyadevi, R.; Aseervatham, S.B. Chemical constituents, in vitro antioxidant and antimicrobial potential of Caryota urens L. Free Radicals Antioxid. 2013, 3, 107-112. [CrossRef]

60. Yang, J.; Yan, R.; Roy, A.; Xu, D.; Poisson, J.; Zhang, Y. The I-TASSER Suite: Protein structure and function prediction. Nat. Methods 2015, 12, 7-8. [CrossRef] 